\title{
Appearing Competent: A Study of Impression Management in US and European CEO Profiles
}

\section{Pre-print version of:}

Pollach, I., Kerbler, E. (2011). Appearing Competent: A Study of Impression Management in US and European CEO Profiles, Journal of Business Communication, 48(4), 355-372.

\section{INTRODUCTION}

A CEO's strong charisma, reputation, and symbolic power can have a positive effect on corporate reputation (Cravens, Oliver, \& Ramamoorti, 2003), corporate performance (Rajagopalan \& Datta, 1996), organizational effectiveness (Fanelli \& Misangyi, 2006; Waldmann, Ramirez, House, \& Puranam, 2001), and financial analysts' stock recommendations (Gaines-Ross, 2000). Companies and their CEOs therefore have an interest in presenting the persona of the CEO as competent vis-à-vis employees, future employees, the financial community, and the press in order to manage audience impressions and justify the CEO's paycheck. Impression management is the process by which people seek to influence impressions others form of them (Rosenfeld, Giacalone, \& Riordan, 1995).

Companies and CEOs have various possibilities to communicate CEO competence to internal and external stakeholder groups. First, the $\mathrm{CEO}$ personifies the organization in media coverage about the company (Park \& Berger, 2004). CEO performance is also periodically assessed by the business press in rankings ranging from World's Best CEOs to Most Admired CEOs, which is clearly more difficult to influence than traditional media coverage. Former superstar CEOs, such as Lee Iacocca or Jack Welch, have also displayed their competence by publishing autobiographies or books on leadership (Riordan, 1989). Ultimately, the corporate website is an obvious place to present the CEO as competent to audiences within and outside the organization.

The presentation of the CEO on a corporate website is not filtered by media gatekeepers before it reaches its audience, as is the case with news media content (White \& Raman, 1999). Another advantage of CEO pages on corporate websites is that this self-presentation occurs in a written, planned format. Unlike face-to-face interactions, such as TV interviews, a written self-presentation does not require spontaneous reactions to particular stimuli (Leary, 1995). This creates ample room for CEOs and companies to manage the audience's impressions of the CEO's competence. However, the audience's expectations of what is normal and acceptable clearly restrict companies' opportunities when presenting their version of CEO competence. This entails that companies find themselves in a situation where they would like to present the $\mathrm{CEO}$ as competent, but at the same time need to be careful not to overdo it in order for the audience to accept the company's version. 
This paper seeks to arrive at a better understanding of how companies and CEOs create impressions of CEO competence when presenting the CEO on the corporate website. Since the notions of competence may not be universally understood in different cultural contexts, this study compares CEO profiles from North American and European company websites to examine whether different business cultures are reflected in the way CEO competence is presented. The paper begins with a review of the literature on impression management, before it describes the content-analytic methodology that was employed. It then presents the quantitative and qualitative results and discusses the differences between North American and European CEO profiles. The results suggest that impression management is more prevalent in North American CEO profiles, which present CEOs as active participants in social, political, and public life, while European CEO profiles present CEOs primarily as businessmen.

\section{CONCEPTUAL BACKGROUND}

When individuals find themselves in situations where they want to present themselves as competent, they are likely to convey self-promoting messages that emphasize relevant personal attributes and achievements, corresponding to what expectations they think others have of a competent person in this position (Ellis \& Wittenbaum, 2000). Impression management is the process by which people seek to influence the images others form of them (Rosenfeld, Giacalone, \& Riordan, 1995). It is a standard element of organizational life, employed to influence the outcomes of job interviews (Ralston \& Kirkwood, 1999), appraisals, and promotion decisions (Giacalone \& Rosenfeld, 1991). Résumés are also conventionalized forms of impression management, in which people translate their selves into a list of assets, attributes, and resources valued in their particular field (Knouse, 1994; Metcalfe, 1992).

Impression management has its theoretical roots in symbolic interactionism, which argues that humans adjust their behavior to the actions of others based on the meanings they attach to these individuals and actions (Blumer, 1963, 1969). Goffman (1959) argued that people manage the impressions others have of them by communicating their desired identity in order to obtain particular outcomes in an interaction. Tedeschi and Melburg (1984) developed a conceptual framework of impression management tactics and strategies based on previous empirical work (Gardner \& Martinko, 1988; Grasmick, 1976; Schlenker, 1980). Their framework consists of assertive impression management, which is applied when an identity is to be developed or enhanced, and defensive ones, which is used when identities are to be protected. Only assertive impression management is relevant in this paper, given that CEO profiles are intended to develop and enhance the persona of the CEO. Those tactics and strategies introduced by Tedeschi and Melburg (1984) that are relevant for CEO profiles are summarized and defined in Table 1.

Job-focused impression management is generally aimed at making employees appear more competent (Bolino et al., 2006). Competence has been conceptualized as a bundle of knowledge, skills and behaviors (LeDeist \& Winterton, 2005) and as a combination of knowledge and 'ways of being' (Sandberg \& Pinnington, 2009). Cheetham and Chivers (1996) propose a more comprehensive framework, consisting of functional competence (possessing the skills to accomplish the tasks of one's job), personal competence (adopting appropriate behavior), cognitive competence (possessing relevant knowledge), and ethical competence (possessing appropriate personal and professional values). The present study relies on this four-tier definition of competence when studying impressions of CEO competence. 


\begin{tabular}{|l|l|}
\hline Self-promotion & Making persons or actions seem better than they actually are \\
\hline Entitlements & Attributing positive outcomes to oneself \\
\hline Enhancements & Claiming that the positive value of an outcome is higher than it actually is \\
\hline Exemplification & Presenting oneself as a role model in a certain area, e.g. integrity \\
\hline Attractiveness & Social desirability \\
\hline Esteem & $\begin{array}{l}\text { Others' perceptions of one's expertise, which is composed of competence, } \\
\text { abilities, experience, and education }\end{array}$ \\
\hline Prestige & $\begin{array}{l}\text { Having informal power, being willing to use it, and displaying it to others. } \\
\text { Prestige is also attached to particular jobs through educational requirements or } \\
\text { income. }\end{array}$ \\
\hline Status & Having a position in a hierarchy from which one derives authority \\
\hline Credibility & Bestowed upon a person, if there is a match between words and deeds \\
\hline
\end{tabular}

(Source: Gardner \& Martinko, 1988; Grasmick, 1976; Schlenker, 1980; Tedeschi \& Melburg, 1984).

Table 1: Assertive Impression Management

\section{RESEARCH DESIGN}

\section{Data}

The goal of this study is to understand how companies create impressions of CEO competence and whether these impressions are different in different cultural contexts. To this end, CEO profiles from 100 North American and 100 European corporate websites were accessed and downloaded. The sample was drawn from the top North American and European companies on the Fortune Global 500 ranking. It was assumed that these companies receive a level of attention that makes the CEO profiles important communication vehicles for the company. We study the European companies first as one sample, since it can be argued that the EU-15 area is one business environment due to a common regulatory framework, integrated consumer markets, and pan-European mergers and acquisitions (Dahan \& Frech, 2008). As it has also been argued that the EU lacks a common culture (Shore, 2000, p. 18), we break the European companies down into cultural clusters, using the clusters developed as part of the GLOBE study (House et al., 2004). It turned out that the Nordic cluster (Sweden, Denmark, Finland) would only have consisted of three companies. Therefore, these companies were removed. A total of 75 companies from North America and 82 from Europe had CEO profiles on their websites. The North American companies in the sample are all headquartered in the US. European companies are distributed as follows: Anglo cluster 27\% (Great Britain), Latin Europe 27\% (Italy, France, Spain, French Swiss), and the Germanic cluster 46\% (Germany, the Netherlands, German Swiss). The units of analysis were CEO profiles from corporate websites. Although CEOs are likely to make an appearance in other parts of the corporate website as well, other pages were not taken into account to ensure that the study has a clearly demarcated unit of analysis (cf. McMillan, 2000). The CEOs in the sample are overwhelmingly male, including only one female CEO from a US company. 


\section{Method of Analysis}

The research process started with a quantitative content analysis of all CEO profiles. The purpose of quantitative content analysis is to systematically condense texts into content categories by applying a coding scheme that produces quantitative indices of textual content (cf. Kolbe \& Burnett, 1991; Krippendorff, 1980; Neuendorf, 2002; Weber, 1985). As part of the coding, all pieces of information contained in CEO profiles were assigned to content categories. A preliminary coding scheme was drawn up from the data by examining the 20 longest texts in the sample to identify relevant categories in an inductive manner (cf. Strauss \& Corbin, 1990). Additional codes emerged in the course of the coding process, resulting in a total of 19 content categories. This inductive procedure ensured that all pieces of information contained in CEO profiles were captured by the categories employed. The 19 categories are listed in Table 2 together with the results. All CEO profiles were initially coded by one author. As a check on inter-coder reliability and consistency, a random sample of 48 texts (30\%) was coded by the second author. Cohen's kappa was 0.963 , which is excellent according to Orwin (1994).

The quantitative content analysis provides a systematic overview of the themes found in CEO profiles, which serves as a basis for a subsequent qualitative content analysis. The combination of quantitative and qualitative content analysis has been recommended in order to overcome the shortcomings of purely quantitative content analysis (Kracauer, 1952; Mayring, 2000; Weber, 1990). Qualitative content analysis is based on constructionist assumptions and focuses on the interpretation of meaning (Morant, 1998). It is especially useful when studying textual patterns that are not accessible to quantitative content analysis (Kracauer, 1952). The qualitative analysis examines which content categories of the quantitative study contribute to impressions of CEO competence. To this end, all CEO profiles were reread closely with a view to reconnecting the content categories with the context of CEOs as social actors and the roles they play in business and society. The approach we have chosen for the analysis of $\mathrm{CEO}$ profiles thus takes into account manifest content by means of quantitative content analysis and latent content by means of qualitative content analysis in a complementary mixed-methods design (cf. Kracauer, 1952; Sale, Lohfeld, \& Brazil, 2002). Together, the two analyses can indicate whether there are differences in the prevalence of impression management in CEO profiles.

\section{RESULTS}

The results of the quantitative analysis are presented in Table 2, which indicates how frequently each of the content categories was found in the North American and European CEO profiles as well as the three European clusters. Most commonly, CEO profiles contain information on the CEO's previous positions, and the year in which he or she joined the company. Non-executive board memberships are mentioned in about half the profiles. That these three categories are the most frequent can be expected, given the raison d'être of CEO profiles. While age is a very frequent category in the Germanic and Latin Europe profiles, it is significantly less frequent in North American and Anglo profiles. This difference is, in fact, the biggest one among all content categories. The absence of age in North American and Anglo profiles may have something to do with the value of privacy, and it is, in fact, recommended not to include this information in résumés in the US (e.g. Hutchinson \& Brefka 1997). Nationality is another category that appears more often in European profiles, especially in the Germanic and Latin European clusters. The higher number of different countries featured in the European sample as well as an awareness of global readership may explain this difference. 


\begin{tabular}{|c|c|c|c|c|c|c|c|c|}
\hline No. & $\begin{array}{l}\text { Content } \\
\text { Categories }\end{array}$ & $\begin{array}{c}\text { N America } \\
(n=75)\end{array}$ & $\begin{array}{l}\text { Europe } \\
(n=82)\end{array}$ & $\begin{array}{c}\chi^{2} \\
(\mathrm{df}=1)\end{array}$ & Anglo & $\begin{array}{c}\text { Germani } \\
\text { c }\end{array}$ & $\begin{array}{l}\text { Latin } \\
\text { Europe }\end{array}$ & $\begin{array}{c}\chi^{2} \\
(d f=2)\end{array}$ \\
\hline 1 & $\begin{array}{l}\text { Previous } \\
\text { positions held }\end{array}$ & $89.3 \%$ & $92.7 \%$ & 0.541 & $95.5 \%$ & $94.7 \%$ & $86.4 \%$ & \\
\hline 2 & $\begin{array}{l}\text { Year joined } \\
\text { company }\end{array}$ & $89.3 \%$ & $85.4 \%$ & 0.555 & $95.5 \%$ & $86.8 \%$ & $72.7 \%$ & \\
\hline 3 & $\begin{array}{l}\text { Non-executive } \\
\text { board } \\
\text { memberships }\end{array}$ & $41.3 \%$ & $45.1 \%$ & 0.229 & $36.4 \%$ & $44.7 \%$ & $54.4 \%$ & \\
\hline 4 & Age, year of birth & $30.7 \%$ & $80.5 \%$ & $39.601 * * *$ & $45.5 \%$ & $89.5 \%$ & $100 \%$ & $24.48^{* * *}$ \\
\hline 5 & Place of birth & $29.3 \%$ & $32.9 \%$ & 0.236 & $9.1 \%$ & $47.4 \%$ & $31.8 \%$ & $9.26 *$ \\
\hline 6 & Nationality & - & $18.3 \%$ & - & $4.5 \%$ & $28.9 \%$ & $13.6 \%$ & 5.987 \\
\hline 7 & Education & $74.7 \%$ & $69.5 \%$ & 0.516 & $40.9 \%$ & $78.9 \%$ & $81.8 \%$ & $11.661^{* * *}$ \\
\hline 8 & Associations & $69.3 \%$ & $20.7 \%$ & $37.562 * * *$ & $18.2 \%$ & $26.3 \%$ & $13.6 \%$ & 1.482 \\
\hline 9 & Success & $29.3 \%$ & $12.2 \%$ & $7.09 *$ & $4.5 \%$ & $21.1 \%$ & $4.5 \%$ & 5.189 \\
\hline 10 & $\begin{array}{l}\text { Company } \\
\text { background }\end{array}$ & $21.3 \%$ & $3.7 \%$ & $11.504^{* *}$ & - & $7.9 \%$ & - & \\
\hline 11 & Awards / orders & $12.0 \%$ & $13.4 \%$ & 0.071 & $13.6 \%$ & $10.5 \%$ & $18.2 \%$ & \\
\hline 12 & $\begin{array}{l}\text { Nominations in } \\
\text { press }\end{array}$ & $20.0 \%$ & $4.9 \%$ & $8.421^{* *}$ & $4.5 \%$ & $7.9 \%$ & - & \\
\hline 13 & $\begin{array}{l}\text { Social stance / } \\
\text { philanthropy }\end{array}$ & $22.7 \%$ & $3.7 \%$ & $12.732 * * *$ & - & $7.9 \%$ & - & \\
\hline 14 & $\begin{array}{l}\text { Political } \\
\text { involvement }\end{array}$ & $14.7 \%$ & $3.7 \%$ & $5.84 *$ & $4.5 \%$ & - & $9.1 \%$ & \\
\hline 15 & Family & $16.0 \%$ & $20.7 \%$ & 0.582 & $13.6 \%$ & $28.9 \%$ & $13.6 \%$ & \\
\hline 16 & Military service & $13.3 \%$ & $1.2 \%$ & 8.822 ** & $4.5 \%$ & - & - & \\
\hline 17 & Residence & $9.3 \%$ & $4.9 \%$ & 1.193 & $9.1 \%$ & $5.3 \%$ & - & \\
\hline 18 & Values & $8.0 \%$ & $3.7 \%$ & 1.366 & $4.5 \%$ & $5.3 \%$ & - & \\
\hline 19 & Hobbies & $4.0 \%$ & $6.1 \%$ & 0.356 & $13.6 \%$ & $5.3 \%$ & - & \\
\hline
\end{tabular}

${ }^{*} \mathrm{p}<0.05,{ }^{* *} \mathrm{p}<0.01,{ }^{* * *} \mathrm{p}<0.001$

Table 2: Content of CEO Profiles 
After job-related information, education is the most frequent category, found in about $75 \%$ of all profiles. Notably, only $40 \%$ of the Anglo profiles contain this information, which is a highly significant difference among the European clusters. The two samples do not differ when it comes to education. All CEOs who include information about their education are college-educated, which confers prestige to an individual (Sernau, 2005, p. 170). There is a tendency for the CEOs in the sample to have completed programs at prestigious universities, which adds esteem in that they convey the impression that the CEO is a member of an elite social class. For example:

... graduated summa cum laude in electrical engineering from the University of California at Los Angeles, where he also received a master's degree and a doctorate in the same field. He subsequently completed executive education programs at Stanford University, the Wharton School of the University of Pennsylvania, and Harvard University.

However, prestigious universities are not that frequent that it can be argued that a degree from a highprestige university is a requirement for becoming the $\mathrm{CEO}$ of a large corporation, as was argued, for example, by Useem and Karabel (1986).

Highly significant differences between Europe and North America were found for leadership functions in associations, such as non-profit organizations, professional associations, trusts, thinktanks, museums, or university boards. Leadership roles and memberships in well recognized associations are an indicator of high social status and prestige (Sernau, 2005, p. 175). To some extent, these affiliations together with non-executive board memberships illustrate Useem's (1984) notion of 'the inner circle', denoting an elite class of CEOs who are connected through board memberships and affiliations with the same organizations and exert influence on policy making through these networks. A similar point is made by Davis et al. (2003) in their network analysis of US CEOs. They argue that "corporate America is overseen by a network of individuals who to a great extent know each other or have acquaintances in common" (p. 321).

The CEO's success on the job is mentioned explicitly in more than a quarter of North American profiles and in several European profiles, particularly Germanic ones. In these profiles, the company's success is attributed to the CEO's competence, as the following statement illustrates:

During his tenure, the company has doubled its revenues to $\$ 80 \mathrm{~B}$, tripled its earnings, expanded into new markets and advanced to no. 15 on the Fortune 500.

In three US profiles, narratives serve to underline the CEO's personality as the key to success. In these profiles, negative information illustrates that the CEOs had to overcome obstacles that made them who they are. For example:

Within weeks of joining the company, Anderson was ready to quit because he had not made a single sale. Then, he discovered the power of asking the right questions and truly listening to the customer's answers. He became a successful sales person and eventually was named store manager.

In other instances, success is attributed to the CEO implicitly when the CEO profile contains background information on the company, such as company size, financial figures, or competitive position. This is found in a few profiles from Germanic Europe and over $20 \%$ of North American profiles. The attribution of success to the CEO is implied, as the company background would otherwise not be presented in the CEO's biography. The CEO is implicitly identified as the causal agent of the company's success, which represents a form of entitlements and enhancements. For example:

McNerney, 56, oversees the strategic direction of the Chicago-based, \$52 billion aerospace company. With more than 153,000 employees, Boeing is the largest manufacturer of commercial jetliners and military aircraft. 
Competence is also constructed through awards, which some of the CEOs list in their profiles. They are equally frequent in North American and European profiles. Awards given to CEOs function as prestige objects, in particular if the awarding institution is of high repute, such as the United Nations or a top business school. The awards given to the CEOs in the sample pertain to four different areas: leadership, corporate citizenship, service to education, and advancement of research. They function as a legitimization of the CEO's position and enhance the CEO's credibility in that they suggest that others perceive this $\mathrm{CEO}$ as competent. Similar to awards, nominations in the press function as markers of credibility, prestige, and self-promotion in that they provide evidence of a CEO's abilities and respect received from outsiders. Unlike awards, nominations in the press occur significantly more frequently in North American CEO profiles (20\% vs. 6.6\%). Such nominations include, for example, Fortune's European Businessman of the Year or Chief Executive Magazine's CEO of the Year. Such nominations are also embedded in laudatory contexts such as the following:

Nardelli's ability to transform, innovate and deliver strong financial returns has gained widespread recognition. In naming him one of 2005's best managers, Business Week stated that he "turned a \$46 billion company focused on big-box stores into a $\$ 70$ billion chain with urban, suburban and international outlets".

Individuals may also gain prestige through philanthropy and social responsibility, since these activities are associated with wealth and power (Sernau, 2005, p. 170). From an impression management perspective, philanthropy represents a form of moral exemplification. When CEO profiles talk about philanthropy and welfare organizations, the CEO is sometimes presented as the causal agent of corporate giving, for example when voluntary hours contributed by employees are presented as the CEO's achievement:

Following The Home Depot's 25 year tradition of investing in local communities through volunteerism and charitable donations, Nardelli led the charge in the company's first ever Week of Service in 2004, when 34,500 associates donated more than 260,000 volunteer hours to complete more than 1,600 community service projects across the country.

This only occurs in North American profiles, and European profiles in fact rarely talk about philanthropic activities. The CEOs' affiliation with leading educational institutions either as alumni or as board members together with their affiliation with professional and philanthropic associations can be seen as a measure of their social capital and influence, highlighting again the formal and informal networks they are a part of (cf. Keiser, 2004).

Political involvement is mentioned more often in North American CEO profiles than in European ones. However, the Latin cluster within the European sample is not significantly different from the North American sample. Political involvement includes, for example, membership in a presidential advisory council, involvement in a presidential campaign as finance chairman, or participation in a governor's commission. Mentioning such appointments serves to construct the CEO as a competent leader whose advice is called upon by high-ranking officials, which contributes to his/her credibility.

Further, some CEO profiles are an interaction of professional and private identities in that they contain information about family status. The humanizing aspect of mentioning names of wives and children gives the CEO a stronger social presence. If mentioned, the CEOs' marital status and family situation is always 'married', which conveys a form of social desirability. Other domestic situations, such as bachelorhood or separations, are absent. In other words, wives and children are explicitly present, but never explicitly absent. This constructs those CEOs whose family status is mentioned as happy family men in addition to being successful businessmen. Success is thus not only a theme of the 
CEOs' professional identities but also carried forward into their private lives. The samples do not differ significantly regarding this category.

Military service is mentioned significantly more often in North American CEO profiles than in European profiles, and it is in fact only mentioned in Anglo European profiles. Depending on the expectations of the audience, mentioning military service can construct the $\mathrm{CEO}$ as a patriot willing to serve his/her country, thereby conveying exemplification. This perception is unlikely to exist in Germanic and Latin Europe, where military service is still compulsory or was so in the past.

Content categories that occur equally infrequently in both samples include the CEOs' residence, values, and hobbies. Values convey exemplification in that they present the $\mathrm{CEO}$ as a role model. They either illustrate how particular decisions were taken because of the CEO's beliefs or represent general views on running a business, managing people, and satisfying customers. For example:

Walter believes that growth and consistent performance can only be achieved through the drive and entrepreneurial spirit of talented people. He insists that employees remain passionate about applying their resources, knowledge and experience in health care to help solve clients' most pressing issues and improve the quality of patient care.

Information on hobbies not only conveys the impression that the CEO has a life outside his/her job (cf. Metcalfe, 1992), but also, to the small extent that they are mentioned, convey prestige when these hobbies are elite hobbies associated with memberships in exclusive clubs, such as golf, tennis or sailing. More mundane leisure activities are absent.

\section{DISCUSSION}

Conceptually, this study is grounded in impression management, since job-related impression management is geared towards appearing more competent (Bolino et al., 2006). The study has revealed that instances of all assertive tactics and strategies introduced are used to create very comprehensive impressions of CEO competence. Table 3 combines the content categories of the quantitative content analysis with the findings of the qualitative content analysis, which has identified 14 content categories as potential impression management strategies. Notably, not all of these 14 content categories always construct CEO competence. Education, for example, can be an instance of prestige, but may not have this characteristic, if the university is less well known. Similarly, not all categories that represent the CEO's social stance or philanthropic activities represent entitlements. Table 3 therefore separates the content categories identified into 'definite' and 'potential', with the former denoting those content categories that always construct impressions of competence. These impressions pertain to functional competence (e.g. success, company background), cognitive competence (e.g. education, political advisory functions), personal competence (e.g. family, leadership in associations, military), and ethical competence (e.g. values, awards, social stance). 


\begin{tabular}{|l|l|l|}
\hline \multirow{2}{*}{ Impression Management } & \multicolumn{2}{|c|}{ Representation in the Text } \\
\cline { 2 - 3 } & Definite & Potential \\
\hline $\begin{array}{l}\text { Status, prestige, } \\
\text { self-promotion, and esteem }\end{array}$ & $\begin{array}{l}\text { Awards } \\
\text { Nominations in press } \\
\text { Social stance }\end{array}$ & $\begin{array}{l}\text { Associations } \\
\text { Education } \\
\text { Hobbies }\end{array}$ \\
\hline Entitlements and enhancements & $\begin{array}{l}\text { Success } \\
\text { Company background }\end{array}$ & Social stance \\
\hline Exemplification & $\begin{array}{l}\text { Social stance } \\
\text { Values }\end{array}$ & Military service \\
\hline Credibility & $\begin{array}{l}\text { Awards } \\
\text { Nominations in press } \\
\text { Political involvement }\end{array}$ & \\
\hline Attractiveness & Family & \\
\hline
\end{tabular}

Table 3: Constructing Competence in CEO Profiles

The paper also examined differences in the impression management of CEO competence by North American and European companies. Where the two samples do not differ is education, which is mentioned frequently in profiles from both continents, but may only have constructive effects when the educational institution is of high repute. North American CEO profiles have been found to construct competence through associations, success, company background, nominations in the press, social stance, political involvement and military service, all of which are found significantly more often in North American profiles than in European ones. They also mention family and awards, but less frequently than the former categories and equally frequent as in European profiles. North American CEOs are thus presented as active participants in social, political, and public life, taking on responsibilities and committing time to activities not directly related to their companies. European CEO profiles, meanwhile, use primarily associations, awards and family as impression management. Thus, European CEOs are presented as more business-focused. They participate in associations, philanthropic activities, and politics to a much smaller extent than their American counterparts. Success is significantly less frequently mentioned either explicitly or by means of including the company background. Overall, 63\% of American CEO profiles contain definite impression management categories, while only $34 \%$ of European profiles contain such content, which is a significant difference $(\mathrm{p}<0.01)$. This suggests that impression management is more prevalent in North American CEO profiles.

We also broke the European companies down into three different country clusters (Anglo, Germanic, and Latin Europe) and found that the Anglo cluster is in some instances different from both North America and the rest of Europe, especially when it comes to age, education, and hobbies. Significant differences between Europe and North America also apply when comparing North America with the three country clusters, namely for associations, social stance, nominations in the press, and company background. Within the three European clusters, the Germanic cluster is the one with the most definite impression management (39\%), e.g. when looking at categories such as social stance, success, associations, company background, and family, while the Anglo cluster is the one with the least impression management efforts (27\%), and the Latin cluster is in the middle (31\%). 
Differences among the three cultures are not significant. Overall, these results thus indicate that North American CEO profiles go to greater lengths to construct their CEOs as competent, as they contain more prestige-laden content categories than European CEO profiles, even when looking at individual cultural clusters. If impression management is seen as an effort to meet or surpass the expectations of one's audience, these differences serve to illustrate the different roles CEOs are expected to play in these two business cultures. Even though there are differences among the European cultural clusters, the prevalence of competence creation is stronger in the North American sample. The reason why the differences between the European clusters were not stronger could be put down to the homogenization of expected CEO competence due to pan-European mergers and acquisitions and increased labor mobility within Europe. Overall, North America and Western Europe thus seem to have different expectations and understandings of CEO competence.

These findings have implications for the design of corporate CEO profiles and the communication of CEO competence. Corporate perceptions of what kind of values and attributes a CEO should exemplify seem to be different in North America and Europe, with North American CEOs being expected to participate in social, political, and public life to a greater extent. It is thus important for international companies to understand the impressions of competence they construct with the presence or absence of certain content categories in their CEO profiles.

The study has limitations in two respects. The first limitation concerns the fact that the sample consists of companies from both English-speaking countries and non-English-speaking countries. The analysis of only English texts may thus distort the findings to some extent. However, the hypercentrality of English as the language of international business (Crystal, 2003) and corporate websites (Kelly-Holmes, 2006) has been established in the literature, which mitigates this limitation. Second, the texts in the sample share the same situational context, but originate from companies operating in a wide range of industries. A limitation may therefore be that the social significance attached to the persona of the CEO is different in different industries.

\section{REFERENCES}

Blumer, H. (1963). Society as symbolic interaction. In A. Rose (Ed.), Human behavior and social processes: An interactionist approach (pp. 179-192). Boston: Houghton Mifflin.

Blumer, H. (1969). Symbolic interactionism: Perspective and method. Berkeley, CA: University of California Press.

Bolino, M. C., Varela, J. A., Bande, B., \& Turnley, W. H. (2006). The impact of impressionmanagement tactics on supervisor ratings of organizational citizenship behavior. Journal of Organizational Behavior, 27, 281-297.

Cheetham, G., \& Chivers, G. (1996). Towards a holistic model of professional competence. Journal of European Industrial Training, 20(5), 20-30.

Cravens, K., Oliver, E. G., \& Ramamoorti, S. (2003). The reputation index: Measuring and managing corporate reputation. European Management Journal, 21(2), 201-212.

Crystal, D. (2003). English as a global language. 2nd. ed. Cambridge: Cambridge University Press. 
Dahan, N. M., \& Frech, W. J. (2008). A review of European business integration: Does European business exist? International Journal of Business Research, 8(5), 15-27.

Davis, G. F., Yoo, M., \& Baker, W. E. (2003). The small world of the American corporate elite, 19822001. Strategic Organization, 1(3), 301-326.

Ellis, J. B., \& Wittenbaum, G. M. (2000). Relationships between self-construal and verbal promotion. Communication Research, 27(6), 704-722.

Fanelli, A., \& Misangyi, V. F. (2006). Bringing out charisma: CEO charisma and external stakeholders. Academy of Management Review, 31(4), 1049-1061.

House, R. J., Hanges, P. J., Javidan, M., Dorfman, P. W., \& Gupta, V. (eds.) (2004), Culture, leadership, and organizations. The GLOBE Study of 62 Societies. Thousand Oaks: Sage.

Gaines-Ross, L. (2000). CEO reputation. A key factor in shareholder value. Corporate Reputation Review, 3, 366-370.

Gardner, W. L., \& Martinko, M. J. (1988). Impression management: An observational study linking audience characteristics with verbal self-presentations. Academy of Management Journal, 31(1), 42-65.

Giacalone, R. A., \& Rosenfeld, P. (1991). From extreme to mainstream: Applied impression management in organizations. In R. A. Giacalone \& P. Rosenfeld (Eds.), Applied impression management (pp. 3-12). London: Sage.

Goffman, E. (1959). The presentation of self in everyday life. Garden City, NY: Doubleday.

Grasmick, H. G. (1976). The occupational prestige structure. The Sociological Quarterly, 17, 90-108.

Hutchinson, K. L., \& Brefka , D. S. (1997). Personnel administrators' preferences for résumé content: Ten years after. Business Communication Quarterly, 60(2), 67-75.

Keiser, J. D. (2004). Chief executives from 1960-1989: A trend towards professionalization. Journal of Leadership \& Organizational Studies, 10(3), 52-68.

Kelly-Holmes, H. (2006). Multilingualism and commercial language practices on the Internet. Journal of Sociolinguistics, 10(4), 507-519.

Knouse, S. B. (1994). Impressions of the resume: The effects of applicant education, experience, and impression management. Journal of Business \& Psychology, 9(1), 33-45.

Kolbe, R. H., \& Burnett, M. S. (1991). Content-analysis research: An examination of applications with directives for improving research reliability and objectivity. Journal of Consumer Research, 18(2), 243-250.

Kracauer, S. (1952). The challenge of qualitative content analysis. The Public Opinion Quarterly 16(4), 631-642.

Krippendorff, K. (1980). Content analysis. An introduction to its methodology. Beverly Hills, CA: Sage.

Le Deist, F. D. \& Winterton, J. (2005). What is competence?, Human Resource Development International, 8(1), 27-46.

Leary, M. R. (1995). Self-presentation: Impression management and interpersonal behavior. Madison, WI: Brown and Benchmark.

Mayring, P. (2000). Qualitative content analysis. Forum: Qualitative Social Research, 1(2). 
McMillan, S. J. (2000). The microscope and the moving target: The challenge of applying content analysis to the World Wide Web. Journalism and Mass Communication Quarterly, 77(1), 8098.

Metcalfe, A. W. (1992). The curriculum vitae: Confessions of a wage-labourer. Work, Employment \& Society, 6(4), 619-641.

Morant, N. (1998). Social representations of gender in the media: quantitative and qualitative content analysis. In D. Miell \& M. Wetherell (Eds.), Doing Social Psychology. London: Sage.

Neuendorf, K. A. (2002). The content analysis guidebook. Thousand Oaks, CA: Sage.

Orwin, R. A. (1994). Evaluating coding decisions. In H. Cooper \& L. V. Hedges (Eds.), The handbook of research synthesis (pp. 139-161). New York: Russell Sage Foundation.

Park, D.-J., \& Berger, B. K. (2004). The presentation of CEOs in the press, 1990-2000: Increasing salience, positive valence, and a focus on competency and personal dimensions of image. Journal of Public Relations Research, 16(1), 93-125.

Pfeffer, J. (1981). Management as symbolic action. In L. L. Cummings \& B. M. Staw (Eds.), Research in organizational behavior 3 (pp. 1-52). Greenwich, CT: JAI Press.

Porter, M. E., \& Nohria, N. (2010). What is leadership? The CEO's role in large, complex organizations. In N. Nohria \& R. Khurana (Eds.), Handbook of leadership theory and practice (pp. 433-474). Cambridge: Harvard Business Press.

Rajagopalan, N., \& Datta, D. K. (1996). CEO characteristics: Does industry matter? Academy of Management Journal, 39(1), 197-215.

Ralston, S. M., \& Kirkwood, W. G. (1999). The trouble with applicant impression management. Journal of Business and Technical Communication, 13, 190-207.

Riordan, C. A. (1989). Images of managerial success. In R. A. Giacalone \& P. Rosenfeld (Eds.), Impression management in the organization (pp. 87-103). Hillsdale, NJ: Lawrence Erlbaum.

Rosenfeld, P., Giacalone, R. A., \& Riordan, C. A. (1995). Impression management in organizations. London: Routledge.

Sale, J. E. M., Lohfeld, L. H., \& Brazil, K. (2002). Revisiting the quantitative-qualitative debate: Implications for mixed-methods research. Quality \& Quantity, 36, 43-53.

Sandberg, J. \& Pinnington, A. H. (2009). Professional competence as ways of being: An existential ontological perspective. Journal of Management Studies, 46(7), 1138-1170.

Schlenker, B. R. (1980). Impression management: The self-concept, social identity, and interpersonal relations. Monterey, CA: Brooks-Cole.

Shore, C. (2000). Building Europe. The cultural politics of European integration. London: Routledge.

Sernau, S. R. (2005). Worlds apart. Social inequalities in a global economy (2nd ed.). Thousand Oaks, CA: Pine Forge Press.

Strauss, A. L., \& Corbin, J. (1990). Basics of qualitative research: Grounded theory procedures and techniques. Newbury Park, CA: Sage.

Tedeschi, J. T., \& Melburg, V. (1984). Impression management and influence in the organization. In S. B. Bacharach \& E. J. Lawler (Eds.), Research in the Sociology of Organizations Volume 3 (pp. 31-58): JAI Press. 
Useem, M. (1984). The inner circle: Large corporations and the rise of business political activity in the US and UK. Oxford: Oxford University Press.

Useem, M., \& Karabel, J. (1986). Pathways to top corporate management. American Sociological Review, 51(2), 184-200.

Verhoeven, J.W.M., Van Rompay, T.J.L., \& Pruyn, T. H. (2007). Let your workspace speak for itself: The impact of material objects on impression formation and service quality perception. Advances in Consumer Research, 34, 669-674.

Waldmann, D. A., Ramirez, G. G., House, R. J., \& Puranam, P. (2001). Does leadership matter? CEO leadership attributes and profitability under conditions of perceived environmental uncertainty. Academy of Management Journal, 44, 134-143.

Weber, R. P. (1985). Basic content analysis. Beverly Hills, CA: Sage.

Weber, R. P. (1990). Basic content analysis. Sage University Paper Series on Quantitative Applications in the Social Sciences, 49.

White, C., \& Raman, N. (1999). The World Wide Web as a public relations medium: The use of research, planning, and evaluation in web site development. Public Relations Review, 25(4), 405-419. 